\title{
Tubular Microdiscectomy versus Conventional Surgery for Sciatica. A Comparative Prospective Enzyme Study
}

\section{Microdiscectomia tubular versus cirurgia convencional para ciática. Estudo comparativo e prospectivo de enzimas}

Mandour Cherkaoui ${ }^{1}$ Kasouati Jalal ${ }^{2}$ Laaguili Jawad ${ }^{1}$ Gazzaz Miloudi ${ }^{1}$ El Mostarchid Brahim ${ }^{1}$

${ }^{1}$ Department of Neurosurgery, Military Hospital Mohammed V, Rabat, Morocco

Address for correspondence Mandour Cherkaoui, Pr, Department of

2 Epidemiology Laboratory and Clinical Research, Military Hospital Neurosurgery, Military Hospital Mohammed V, Rabat, Morocco Mohammed V, Rabat, Morocco (e-mail: mandour1978@hotmail.com).

Arq Bras Neurocir 2021;40(1):33-36.

\begin{abstract}
Objective Muscle injury is inevitable during surgical exposure of the spine, and it is quantified by the release of creatine phosphokinase. The aim of the present study is to make a comparison between tubular microdiscectomy and conventional microdiscectomy by using the pre- and postoperative serum concentrations of creatine phosphokinase as an indicator of muscle injury.

Materials and Methods A total of 28 patients who underwent surgery for lumbar disc herniation were allocated into 2 groups: 12 patients (group A) operated by transflaval microdiscectomy, and 16 patients (group B) operated by tubular microdiscectomy. The serum concentration of total creatine phosphokinase was measured before surgery (creatine phosphokinase 1 ) and 1 day after surgery (creatine phosphokinase 2 ).

Results There were 12 women and 16 men; the mean age of the patients and the mean duration of the surgery were respectively 49.5 years and 56 minutes for group $A$,

Palavras-chave

- enzima

- hérnia

- microdiscectomia

- ciática

- tubular and 47.3 years and 60 minutes for group $B$. The $p$-values of creatine phosphokinase 1 , creatine phosphokinase 2 and the creatine-phosphokinase ratio were respectively 0,$34 ; 0,31$; and $0,57(p<0.05)$.

Conclusion The present study demonstrated that there was no significant difference between tubular microdiscectomy and conventional microdiscectomy according to the analysis of the levels of creatine phosphokinase.
\end{abstract}

received

March 30, 2020

accepted

August 5, 2020

published online

October 16, 2020
DOI https://doi.org/

10.1055/s-0040-1718429. ISSN 0103-5355.

\footnotetext{
(c) 2020. Sociedade Brasileira de Neurocirurgia. All rights reserved. This is an open access article published by Thieme under the terms of the Creative Commons Attribution-NonDerivative-NonCommercial-License, permitting copying and reproduction so long as the original work is given appropriate credit. Contents may not be used for commercial purposes, or adapted, remixed, transformed or built upon. (https://creativecommons.org/ licenses/by-nc-nd/4.0/)

Thieme Revinter Publicações Ltda., Rua do Matoso 170, Rio de Janeiro, RJ, CEP 20270-135, Brazil
} 


\begin{abstract}
Resumo
Keywords

- enzyme

- hernia

- microdiscectomy

- sciatica

- tubular

Objetivo A lesão muscular é inevitável durante a exposição cirúrgica da coluna vertebral, e é quantificada pela liberação de creatina fosfoquinase. O objetivo deste estudo é fazer uma comparação entre microdiscectomia tubular e microdiscectomia convencional usando creatina fosfoquinase sérica pré e pós-operatória como indicador de lesão muscular.

Materiais e Métodos Um total de 28 pacientes submetidos a cirurgia de hérnia de disco lombar foram alocados em 2 grupos: 12 pacientes (grupo A) operados por microdiscectomia transflaval, e 16 pacientes (grupo B) operados por microdiscectomia tubular. A concentração sérica de creatina fosfoquinase total foi medida antes da cirurgia (creatina fosfoquinase 1) e 1 dia após a cirurgia (creatina fosfoquinase 2 ). Resultados Havia 12 mulheres e 16 homens; a média de idade dos pacientes e o tempo médio da cirurgia foram respectivamente de 49,5 anos e 56 minutos para o grupo A, e de 47,3 anos e 60 minutos para o grupo B. Os valores de $p$ da creatina fosfoquinase 1 , da creatina fosfoquinase 2 , e a razão creatina-fosfoquinase foram, respectivamente, 0,$34 ; 0,31$; e $0,57(p<0,05)$.

Conclusão Este estudo demonstrou que não houve diferença significativa entre microdiscectomia tubular e microdiscectomia convencional de acordo com a análise dos níveis de creatina fosfoquinase.
\end{abstract}

\section{Introduction}

Unilateral transflaval microdiscectomy is the gold standard surgical procedure for the treatment of patients with symptomatic lumbar disc herniation. ${ }^{1}$ However, minimally-invasive procedures (such as tubular microdiscectomy) have gained increasing attention over the last decade, based on the concept of lower muscle damage. $^{2}$

The level of serum creatine phosphokinase in the postoperative period has been considered a suitable parameter to estimate muscle injury in various spinal procedures; ${ }^{3}$ for this reason, we used this marker to compare these two surgical techniques through a prospective study.

\section{Material and Methods}

\section{Patient Selection}

Between June 2019 and February 2020, 28 patients were surgically treated for sciatica due to lumbar disc herniation diagnosed by lumbar magnetic resonance imaging.

In total, 12 patients (group A) were operated by transflaval microdiscectomy, and 16 patients (group B) were operated by tubular microdiscectomy.

The inclusion criteria for the present study were no pathological history (no medical or surgical history or medication taken that may affect the levels of creatine phosphokinase, and a single-level disc herniation requiring a onesided approach. All cases were opereted by the same neurosurgeon.

\section{Surgical Procedure}

Surgery was performed under general anesthesia with the patient in the genupectoral position.
Group A: conventional microdiscectomy was performed after subperiosteal dissection of the ipsilateral paravertebral muscles. The herniated disc was removed by the unilateral transflaval approach with the aid of microscope magnification.

Group B: tubular microdiscectomy; the skin was retracted laterally, and the guide wire and sequential dilators were placed at the inferior aspect of the lamina under fluoroscopic control. The herniated portion of the disc was removed through the tubular retractor with microscopic magnification.

In both procedures, subtotal discectomy was intended, and bony removal was minimal, if necessary.

In the postoperative period, all patients were mobilized and discharged as soon as possible to resume their regular activities whenever possible.

Measurement of creatine phosphokinase: the serum concentration of total creatine phosphokinase was measured before surgery (creatine phosphokinase 1 ) and 1 day after surgery (creatine phosphokinase 2). The normal serum creatine phosphokinase concentration in our hospital is 24 $\mathrm{IU} / \mathrm{L}$ to $195 \mathrm{IU} / \mathrm{L}$.

\section{Results}

Demographics and surgical characteristics ( - Table 1 ): a total 28 patients with lumbar disc-related sciatica were surgycally treated by tubular microdiscectomy and unilateral transflaval microdiscectomy. The sample was composed of 12 women and 16 men, and there were 19 cases of hernia at the L4-L5 level, and 09 cases at the L5-S1 level.

The mean of age of the patients and the mean duration of the surgery were respectively 49.5 years and 56 minutes for group A, and 47.3 years and 60 minutes for group $B$. 
Table 1 Demographic data: age; gender; level and duration of the surgery

\begin{tabular}{|l|l|l|}
\hline & $\begin{array}{l}\text { Conventional } \\
\text { microdiscectomy } \\
\mathrm{N}=12\end{array}$ & $\begin{array}{l}\text { Tubular } \\
\text { microdiscectomy } \\
\mathrm{N}=16\end{array}$ \\
\hline Age (years) & $60-28(49.5)$ & $63-27(47.3)$ \\
\hline $\begin{array}{l}\text { Sex (female/ } \\
\text { male:F/M) }\end{array}$ & $03 \mathrm{~F} / 09 \mathrm{M}$ & $09 \mathrm{~F} / 07 \mathrm{M}$ \\
\hline $\begin{array}{l}\text { Mean of duration } \\
\text { of the surgery } \\
\text { (minutes) }\end{array}$ & 56 & 60 \\
\hline $\begin{array}{l}\text { Disc hernia level } \\
\text { and number } \\
\text { of cases }\end{array}$ & $\begin{array}{l}\text { L4-L5/L5-S1 } \\
06 / 06\end{array}$ & $\begin{array}{l}\text { L4-L5/L5-S1 } \\
13 / 03\end{array}$ \\
\hline
\end{tabular}

Abbreviations: $L 4$, fourth lumbar vertebra; $L 5$, fifth lumbar vertebra; $S 1$, first sacred vertebra.

The postoperative follow-up was simple for all patients, without complications, and with a similar clinical improvement regarding the two techniques.

Serum creatine phosphokinase (-Table 2): the mean concentration of creatine phosphokinase 1 was of 85.81 $\mathrm{IU} / \mathrm{L}$ for tubular microdiscectomy, and of $105.66 \mathrm{IU} / \mathrm{L}$ for conventional microdiscectomy; the mean concentration of creatine phosphokinase 2 for tubular microdiscectomy and conventional microdiscectomy was of $289.06 \mathrm{IU} / \mathrm{L}$ and of 36025 IU/L respectively. The mean creatine-phosphokinase ratio (creatine phosphokinase 2 /creatine phosphokinase 1 ) was of 4.01 for tubular microdiscectomy, and of 3.58 for conventional microdiscectomy.

The statistical analysis showed no significant difference between both procedures regardinge creatine phosphokinase 1 , creatine phosphokinase 2 , and creatine phosphokinase ratio, because the statistical significance was set at the probability level of 0.05 .

\section{Discussion}

The most common cause of sciatica is a herniated lumbar disc; even though lumbar disc surgery is frequently performed, the preferred technique was until recently an important point of debate. Based on the hypothesis that "small is better," efforts have been made to decrease tissue damage through smaller corridor approaches. ${ }^{2}$
The concept of minimally-invasive spine surgery comprises reduced muscle injury while achieving a good clinical outcome comparable with conventional open surgery.

The patients are expected to have less intense low-back pain, shorter hospitalization time, faster mobilization, and to recover. ${ }^{4}$

Several proteins have been widely used in medicine as markers of tissue damage, such as creatine phosphokinase, which is the most widely used blood parameter for the detection of striated muscle injury, ${ }^{5,6}$ and it reaches a maximal concentration one day after surgery. ${ }^{7,8}$

A clear dose-response relationship between creatine phosphokinase and the extent of the surgical invasiveness has been shown, ${ }^{9}$ as well as relationships with the pressure exerted by the retractors on the paraspinal musculature and the duration of this pressure (operating time). ${ }^{10}$

In the present prospective study, we performed a quantitative analysis of muscle injury measured by serum creatine phosphokinase. No significant differences were found regarding creatine phosphokinase 1 , creatine phosphokinase 2 , and the creatine-phosphokinase ratio between tubular microdiscectomy and conventional microdiscectomy.

This result is in line with other results published in the literature, ${ }^{11,12}$ and we explain this non-significant difference by the fact that conventional microdiscectomy is performed through a small incision with lower muscle damage, especially in the case of single-level surgeries. Therefore, in our opinion, conventional unilateral transflaval microdiscectomy can be considered a minimally-invasive procedure as well.

The main limitation of the present study is the small sample, the lack of clinical evaluation in relation to serum creatine phosphokinase, and the lack of a postoperative evaluation of the functional outcome and pain intensity on the visual analog scale; therefore, the clinical significance of our results is not known.

\section{Conclusion}

The release of creatine phosphokinase is an indicator of muscle injury during the surgical exposure of the disc hernia. The present study showed that tubular microdiscectomy is equally invasive as conventional microdiscectomy in terms of creatine phosphokinase for single-level surgeries, with similar surgical outcomes.

Table 2 Serum concentrations of creatine phosphokinase

\begin{tabular}{|l|l|l|l|}
\hline CPK & $\begin{array}{l}\text { Conventional microdiscectomy } \\
\mathbf{N}=\mathbf{1 2}\end{array}$ & $\begin{array}{l}\text { Tubular } \\
\text { microdiscectomy } \\
\mathbf{N}=\mathbf{1 6}\end{array}$ & $\begin{array}{l}\mathbf{p} \text {-value } \\
(<\mathbf{0 . 0 5})\end{array}$ \\
\hline Mean CPK 1 & $(200-57) 105.66 \mathrm{IU} / \mathrm{L}$ & $(280-18) 85.81 \mathrm{IU} / \mathrm{L}$ & 0.34 CPK1 \\
\hline Mean CPK 2 & $(843-123) 360.25 \mathrm{IU} / \mathrm{L}$ & $(640-23) 289.06 \mathrm{IU} / \mathrm{L}$ & $0.31 \mathrm{CPK} 2$ \\
\hline Mean CPK ratio & 3.58 & 4.01 & 0.57 CPK ratio \\
\hline
\end{tabular}

Abbreviations: CPK, creatine phosphokinase; IU/L, International unit per liter. 
36 Tubular Microdiscectomy versus Conventional Surgery for Sciatica Cherkaoui et al.

\section{Conflict of Interests}

The authors have no conflict of interests to declare.

\section{References}

1 Arts M, Brand R, van der Kallen B, Lycklama à Nijeholt G, Peul W. Does minimally invasive lumbar disc surgery result in less muscle injury than conventional surgery? A randomized controlled trial. Eur Spine J 2011;20(01):51-57

2 Akçakaya MO, Yörükoğlu AG, Aydoseli A, et al. Serum creatine phosphokinase levels as an indicator of muscle injury following lumbar disc surgery: Comparison of fully endoscopic discectomy and microdiscectomy. Clin Neurol Neurosurg 2016;145:74-78

3 Iglesias DL, Granell JB, Ribero TV. Validity of Creatine Kinase as an Indicator of Muscle Injury in Spine Surgery and its Relation with Postoperative Pain. Acta Orthop Belg 2014;80(04): 545-550

4 Arts MP, Brand R, van den Akker ME, Koes BW, Bartels RH, Peul WCLeiden-The Hague Spine Intervention Prognostic Study Group (SIPS). Tubular diskectomy vs conventional microdiskectomy for sciatica: a randomized controlled trial. JAMA 2009;302(02): 149-158

5 Achalandabaso A, Plaza-Manzano G, Lomas-Vega R. Tissue Damage Markers after a Spinal Manipulation in Healthy Subjects: A Preliminary Report of a Randomized Controlled Trial. Dis Mark 2014
6 Shin DA, Kim KN, Shin HC, Yoon DH. The efficacy of microendoscopic discectomy in reducing iatrogenic muscle injury. J Neurosurg Spine 2008;8(01):39-43

7 Kawaguchi Y, Matsui H, Tsuji H. Back muscle injury after posterior lumbar spine surgery. A histologic and enzymatic analysis. Spine 1996;21(08):941-944

8 Kawaguchi $\mathrm{Y}$, Matsui $\mathrm{H}$, Tsuji $\mathrm{H}$. Changes in serum creatine phosphokinase MM isoenzyme after lumbar spine surgery. Spine 1997;22(09):1018-1023

9 Arts MP, Nieborg A, Brand R, Peul WC. Serum creatine phosphokinase as an indicator of muscle injury after various spinal and nonspinal surgical procedures. J Neurosurg Spine 2007;7(03): 282-286

10 Kotil K, Tunckale T, Tatar Z, Koldas M, Kural A, Bilge T. Serum creatine phosphokinase activity and histological changes in the multifidus muscle: a prospective randomized controlled comparative study of discectomy with or without retraction. J Neurosurg Spine 2007;6(02):121-125

11 Arts MP, Brand R, van den Akker ME, et al. Tubular diskectomy vs conventional microdiskectomy for the treatment of lumbar disk herniation: 2-year results of a double-blind randomized controlled trial. Neurosurgery 2011;69(01):135-144, discussion 144

12 Hernández-Vaquero D, Fernández-Fairen M, Torres-Perez A, Santamaría A. [Minimally invasive surgery versus conventional surgery. A review of the scientific evidence]. Rev Esp Cir Ortop Traumatol 2012;56(06):444-458 